\title{
THE PALAEOKARST OF CHIOS AND PHOLEGANDROS - TYPES OF WIDESPREAD KARST GENERATIONS IN GREECE
}

\author{
H. RIEDL ${ }^{1}$
}

\section{ABSTRACT}

In contrast to the Miocene polje karst (Chios) with deeply incised v-shaped valleys and kehltoler the Plio/ Pleistocene polje karst (Pholegandros) is marked by the association of pediments, glacis and coastal marginal pediments. Moreover the axes of the karst basins don't reach some decakilometers like in the case of the Miocene poljes, but only a few kilometers of length. Typical of the Plio/Pleistocene karst is the absence of open ponors and often dominates the diffuse drying up of the winterly precipitation on allochthonous sandy clay-fillings of the polje's bottom. The genesis of both palaeokarst types is closely controlled by the palaeoclimate.

KEY WORDS: Reliefgenerationen, Morphodynamik, Klimageomorphologie, Ägäische Inseln, Peloponnes, Festlandgriechenland.

Relief generation, morphodynamics, climato-morphology, Aegean islands, Peloponnese, Continental Greece.

\section{INTRODUCTION}

There exist only a few investigations about palaeokarst in continental Greece. In the Cyclades and East Aegean islands there don't exist any papers dealing with these topics. Untill now neotectonic aspects dominate the investigation of the continental karst basins (Vavliakis, et al. 1980). The author worked above all the last 40 years on the Cyclades, Eastaegean islands and Northern Sporades also in continental Greece and Peloponnese and observed mainly climato-morphological aspects (Riedl, 1984a, 1984b).

With regard to the genesis of poljes we know two theories: the genesis of poljes in the level of the piezometric surface of the karstwater-body and on the other hand the genesis of poljes on the level of insoluble alluvial sediments. At the first model the polje-bottom is explained as success of solution of all the carbonate rocks up to the karst water table and general base level of erosion (Cvijic, 1893, Grund, 1903, Zqtl, 1961, 1974). This is the case in tropical karst, where marginal karst plains are cutting through all the strata, and the polje-bottoms are connected with the base levels of erosion (Lehmann, 1954, Wissmann, 1954).

The second model represents the genesis of poljes sometimes high above the base levels of erosion and independent of the piezometric surface of the karstwater-body. Louis (1956) described the example of Taurus poljes, in which the swallow holes are filled with insoluble material from alluvial fans. Under such circumstances corrosion at the margins of the poljes can be very successful and at the margins of the alluvial fans originate systematically new karst plains cutting all the structures.

\section{CHIOS}

The ancient karst of Chios island situated in the Pelagonian Zone (Jacobshagen, 1978) appears with its large morphological units more outstanding, than the Neogene palaeokarst of Cyclades or of Northern Sporades. The specific character of the palaeokarst on Chios consists of poljes, large marginal karst plains and ancient flat floored valleys, which are all covered by fluvial sediments and lake deposits of Miocene age. As in the whole Aegean Archipelago the large-scale continental style of forms stands in contradiction to the small-scale recent islands. North Chios shows a complex $16 \mathrm{~km}$ long hollow form, striking NE-SW, which traverses nearly the whole island from Kardamila as far as the bay of Elintas. The ancient valley presents at a height of $540 \mathrm{~m}$ a valley-watershed $2 \mathrm{~km} \mathrm{SW}$ from Pitious. The valley like hollow form is drained in SW-direction by Dipotamos River, which is $11 \mathrm{~km}$ long, and in NE-direction by Rachis River with a length of $5 \mathrm{~km}$. The NE-part of the kehltalung (Louis, 1967) of Pitious presents a clear width of 3,5-4 km and a bottom's width of 0,3-0,5 km. The relict bottom is $20-50 \mathrm{~m}$ deep dissected by Rachis river. Important is, that Neogene covers the relict valley bottom in a thickness of only a few meters to a few decameters. From the morphographical point of view we have 


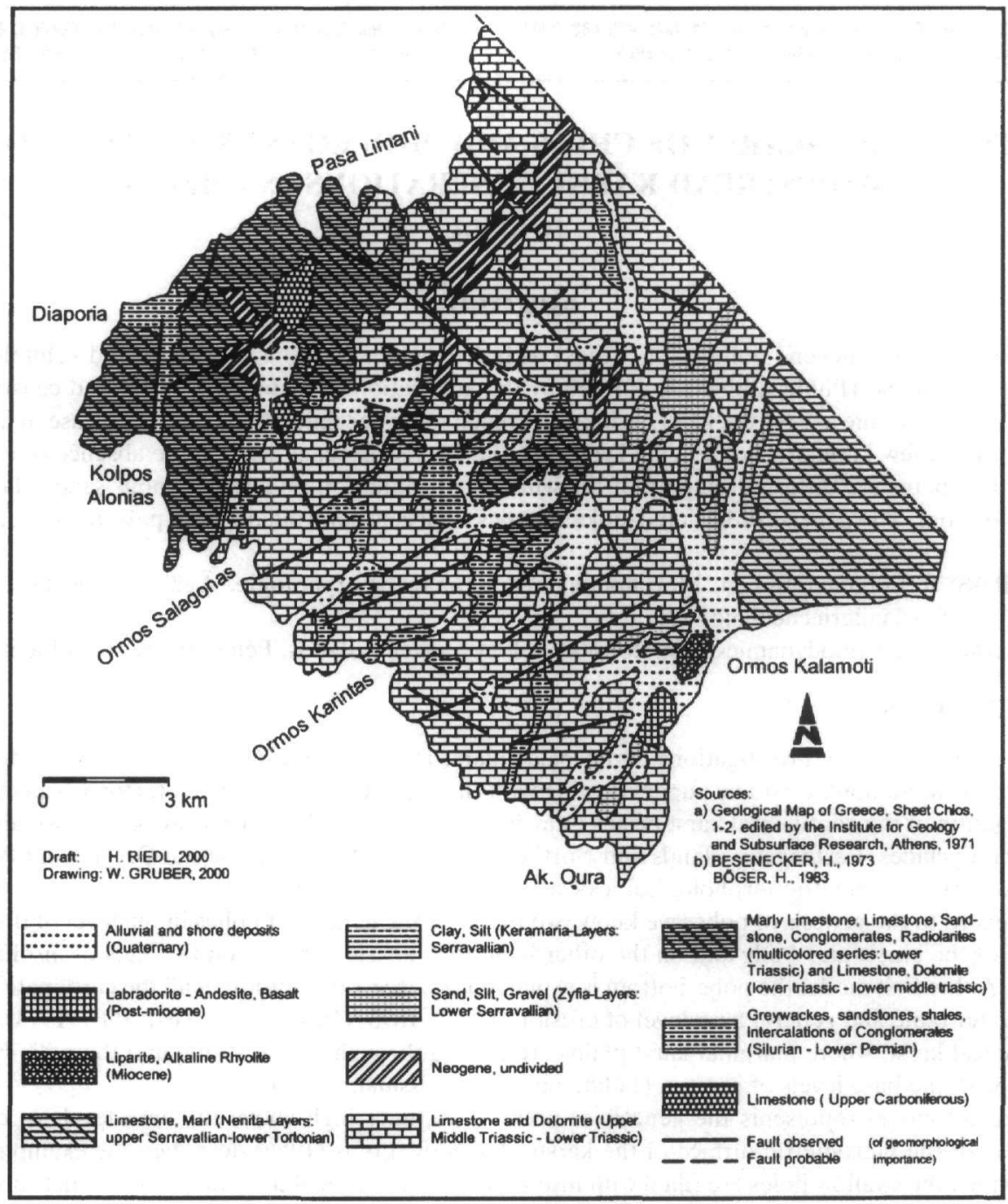

Fig1. Geological map of SW-Chios (simplified)

to take into consideration a polje, because hums are forming the boundary of the hollow form in its SW- and NE-part. The relict karst basin is situated in massively bedded Anisian limestones. The bottom of the polje cuts these strata in a discordant way. The Neogene consists of yellow and brown coarse sands, green-grey loams and yellow marls. These sediments are similar to the Zyfia-layers in SW-Chios (Besenecker, 1973) and were accumulated in Early Serravallian (B $\varphi$ ger, 1983) by a river system having drained the region of greywackes. The transformation of the Middle-Miocene valley with basal notch (Louis, 1967) into a polje happened at the level of the karstwater table during Early Serravallian. For lateral corrosion and the polje's genesis in the level of an ancient piezometric surface the palaeoclimate was a determinant factor. Subtropical leaf-findings of laurel and cinnamon tree (Besenecker, 1973) in the Zyfia-layers indicate an ancient vegetation zone, whose related species are found recently in the forests of south-eastern Asia (Zonobiom V after Walter, 1984). That suggests also the petrified forest of Lesvos, which is buried by the Sigri pyroclastic formation (Velitzelos, Zouros, 1998). At last the somewhat younger Keramaria-layers bear witness of a semihumid tropical savannah-like palaeoclimate on grounds of the mammal-fauna from Younger Serravallian up to Tortonian (B pger, 1983). Therefore the large relict polje of Pitious was already subsided in Middle Miocene as low as $250 \mathrm{~m}$ relating to the marginal karst plain of Rachonas in the east and relating to the peneplain of Oros-Pelinaion in the west as low as $860 \mathrm{~m}$. That also show phenorhyolitic ignimbrites (Herget, 1968, Besenecker, 1973) of Upper Middle Miocene at an altitude 


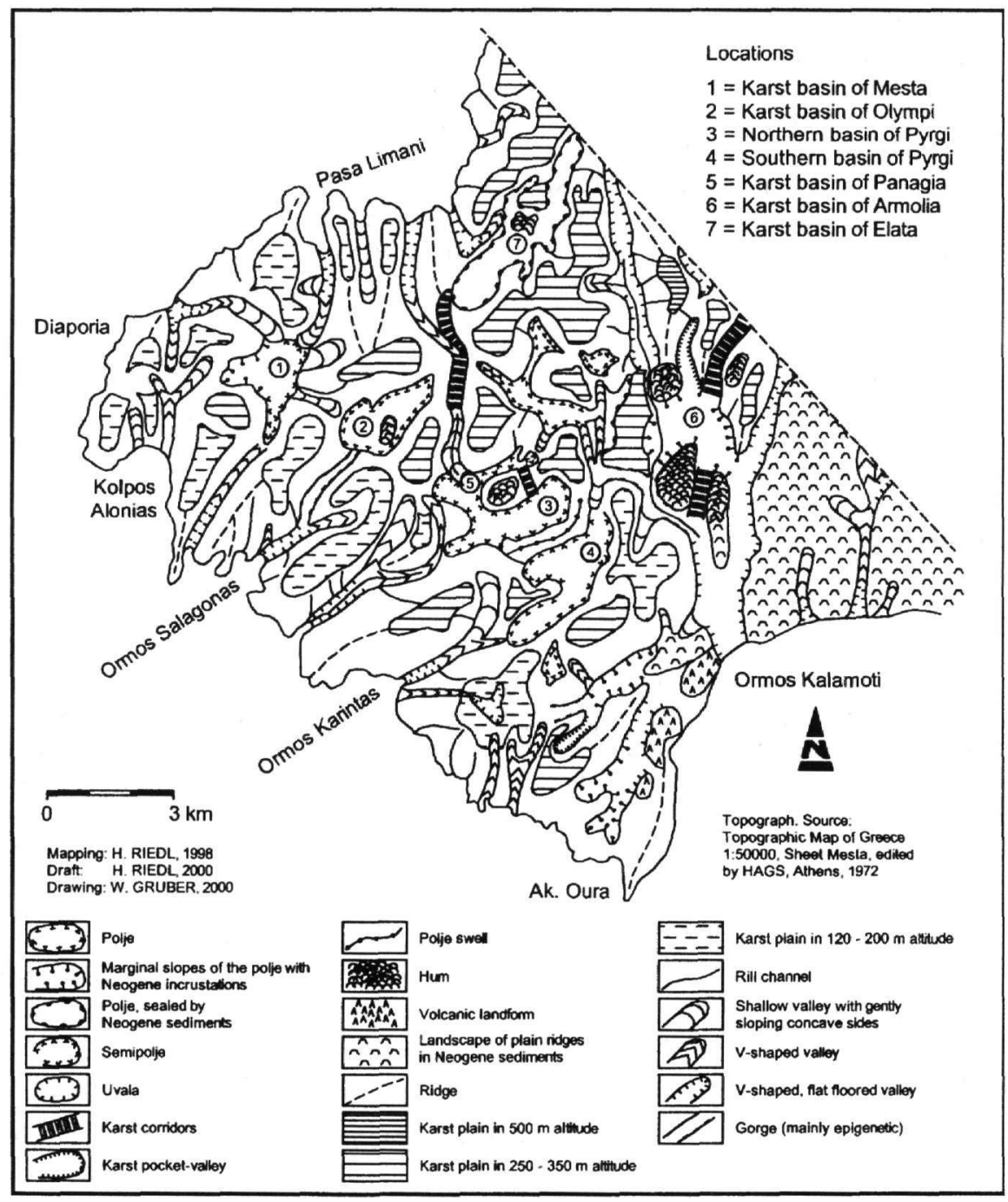

Fig2. Geomorphological Map of SW-Chiow

of $560 \mathrm{~m}$ on the western slopes of the polje. In Post-Middle Miocene time the polje had been uplifted, in the course of which the karstwater table comparatively was lowered at simultaneously beginning of dissection. The Miocene polje had been transformed by pediments with an inclination of $7-10^{\circ}$, covered by Young Pleistocene alluvial accumulations. Together with backwards-erosion of Rachis river, the Miocene sediments got removed and the polje together with its hums was exhumed.

The palaeokarst of SW-Chios (Fig. 1,2) is characterized by a similar high degree of relief energy like in Northchios. The karst basin of Armolia with thick fillings by the Zyfia-layers, which go lower than the recent marine surface, represents one example. Another example offers the relict karst basin of Elata with a length of $6 \mathrm{~km}$ and a width of $1,5 \mathrm{~km}$. The Miocene shows a minimum thickness of $120 \mathrm{~m}$. The whole in Triassic and Jurassic limestones situated karst basin of Elata is independent from the recent morphology of valleys and coasts. South of the relict karst basin of Elata are situated from W to E: the large basins of Mesta, Olympi and the double basin of Pyrgi. Between this row of large karst basins of Mastichochora and the incrusted karst basin of Elata 5 very small karst basins are located. The medium distance of all hollow forms amount to only $1 \mathrm{~km}$. All the large karst basins show NE-SW linear extension controlled by NE-striking faults. All the margins of the basins are situated in Mesozoic and Palaeozoic carbonate rocks with a high degree of solubility. But in the large basins of Mastichochora we notice near the basis of the slopes outcrops of non soluble schists, quartzites and 
conglomerates of Palaeozoic age. Herewith the large poljes of Mastichochora must be termed as semipoljes. The developed basin-bottoms in $110 \mathrm{~m}$ altitude (Mesta), at a height of $140 \mathrm{~m}$ (Olympi) and $100 \mathrm{~m}$ (Pyrgi) consist of sand, clay, allochthone red soils, gravel and debris. In the basin of Mesta the Miocene gravel bearing marls plunge eastward below the Pleistocene/Holocene accumulations. Thereby one might assume also for the other large semipoljes of Mastichochora a Miocene primary age. The northern row of small basins reaches only to a length of 1-2 km. The axes are bound at NW-SE striking faults. The bottoms of the poljes are placed with altitudes of 160-280 m higher than the semipoljes of Mastichochora. The northern small basins constitute except the basin of Panagia typical poljes. All the semipoljes and poljes in SW-Chios represent primary allround closed morphological units with subterranean draining. Only in Postneogene time the basins were opened and integrated within the modern fluvial pattern.

The palaeokarst of Chios therefore was shaped during the ancient stage of continental development long before the genesis of the island. By Early Lower Miocene-Late Upper Miocene accumulation of tropical-subtropical savannah rivers and lakes, the palaeokarst has been buried. The post Neogene mainly Younger Pleistocene dominant fluvial linearerosion, hand in hand with pedimentation of slopes produced the exhumation of the Middle Miocene palaeokarst.

\section{PHOLEGANDROS}

In SE-Pholegandros the hogback relief, similar to the landscape of Cuestas (Fig.3), determined by marbles of the Attic-Cycladic complex, is marked by large pediments. For instance a pediment leads from Oros Elevtherios to the flat pass of Chora at a height of $200 \mathrm{~m}$. The Panagia-hogback also gets bordered by proximal $7^{\circ}$ inclined marble-pediments on the front slopes of the cuesta. On Ag. Pnevma-hogback the pediment developed at a height of 190-230 m, running through the same hogback as pediment-gap; it interlocks with the broad subsequence zone of Petousis in 220-234 m altitude. In a similar manner the pediment breaks through the PetaliProph. Ilias hogback at a height of $230 \mathrm{~m}$. By those pediment-flat passes the hogbacks are transformed to karst - cupolas. Important is, that the pediments cut the limnic-terrestrial Pliocene and therefore must belong to the Plio/Pleistocene (Oldest Pleistocene) pediment-glacis generation of the intramontanous basins in continental Greece and Peloponnese and must be in accordance with the coastal marginal pediments of Cyclades (Riedl, 1982b, 1984b).

The pediments function as controlsystem of the karst basins, which are deepened into the pediments. The flat pass of Chora Pholegandros, consisting of Pliocene, represents the initial genetical plain for the genesis of the polje at a height of $170-200 \mathrm{~m}$ with a length of $1,250 \mathrm{~m}$ by a width of $250-400 \mathrm{~m}$. The largest part of the polje is laid out on marble. The karst basin primarly had subterranean discharge. On it, the canyon shows it, which nowadays drains the subsequent structured polje, dissecting it in SE direction towards the coast with 160\%o angle of inclination. The canyon follows partly cave-systems dependent on E-W and N-S striking faults. The joints are incrusted by red soils and calc-sinter. After the subterranean discharge, the fluvial linear erosion started. The polje's genesis happened after the erosion of the Plio/Pleistocene pediments and before the accumulation of Middle Pleistocene and Wórmian talus stretching into the canyon. There, the polje of Pholegandros has probably Older Pleistocene age. The polje's opening and the destruction of subterranean drainage must be happened therefore in the course of faulting tectonics in the Late Older Pleistocene and during the genesis of the island on the turns of Lower Pleistocene to Middle Pleistocene.

The subsequent pedimented pattern of Petousis is deepened by a polje in the region of Ag. Nikolaos and easterly of it. The polje is incised by a small gorge. The subsequent zone, transformed in an uvala westerly from the hamlet Petousis ends in $160 \mathrm{~m}$ altitude in a cockpit doline, to which all shallow valleys converge with gently sloping concave sides. In this way hogback cupolas are finally transformed into karst cupolas. It is essential that the sequence: Polje - uvala - cockpit doline at 140-160 m height shows an elbow of capture by the Geras river. The fluvial capturing has been promoted by the marine retreat during Wórmian stage.

So we are seeing that in the Cyclades pediments and poljes developed as typical sequence of geomorphological elements in Plio/Pleistocene and Older Pleistocene.

The investigations of Thunell (1979) about the Late Neogene deep-sea drilling sequences from the Mediterranean, the investigations of Marasti et. al (1979) about the palaeoclimatic meaning of Pliocene mollusces in the Mediterranean, and the analyses of Frydas (1998) about Upper Pliocene diatoms and silico-flagellates show in regard to the Upper Pliocene a tropical-subtropical palaeoclimate. Upper Pliocene, allochthonous red soils, alternating with the Upper Pliocene marls on Pholegandros, correspond with the biooecological results. Since 3.2. M.a B.P. (Thunell, 1979) a cooler climate phasis existed with summerly seawater temperature means of only 


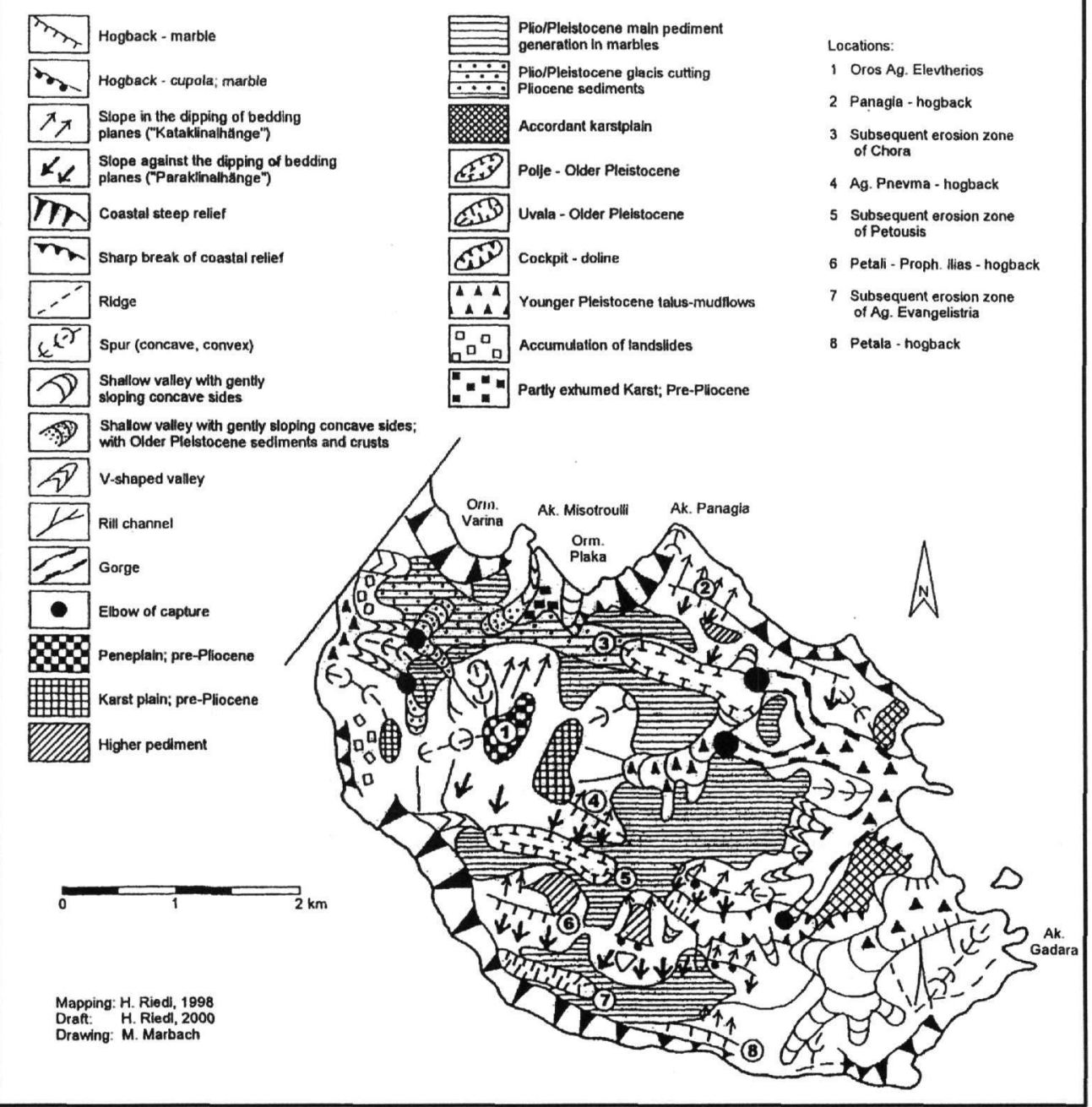

Fig3. Geomorphology of SE-Folegandros

$14^{\circ} \mathrm{C}$. In the Aegean continental stage we notice a stronger drainage phasis at the beginning of Oldest Pleistocene. In this phasis the patterns of pedimentation were established by resequent and obsequent fluvial elements. It is proved to be seen, that still in Plio/Pleistocene the warm features of climate returned until the Older Pleistocene (Blanc Vernet, 1979) being substantiated by the widening of resequent and obsequent rill channels to triangular embayments of the pediments and pediment flat passes. The Plio/Pleistocene - Older Pleistocene sequence of pediments and poljes shows clearly, that the pediments and poljes, connected with the hogbacks, originated not only under tropical-subtropical climate, but also under the morphological conditions of an extensive continental development in the area of the Attic-Cyclades complex. Pediments, uvalas and cockpit dolines were formed by entire independence of the recent coastal geomorphology and the recent valley system of the island.

\section{COMPARING REMARKS}

The palaeokarst of Samos (Riedl, 1989) is very similar to Chios not only relating to the Middle Miocene age but also to the tropical-subtropical heritage of geomorphology. On the topping Karvouni-level (1070 m mean altitude) karst corridors are several meters wide and end in cockpit dolines, which indicate a time of intensive, deep corrosion. Simultaneously haematitic palaeosoils developed. In terms of correlate deposits, this palaeokarst may be compared with the Upper Serravallian base gravels of the basin of Mytilini (Meiíner 1976, B $\varphi$ gner, 
1989). In Upper Serravallian also the mountainous region of Palaeokastron was structured by large poljes, whereas in the Thio Mountains cone and dome-shaped karst forms developed. Simultaneously with the epirogenetic downthrusts in the Tortonian the large poljes were buried up to $300 \mathrm{~m}$ present-day altitude by Upper Miocene sediments. The rate of the uplift of the Middle Miocene palaeokarst on Eastern Samos, however, is $700 \mathrm{~m}$ less than that of the mountains in central Samos.

The Middle Miocene karst generation shows a high degree of similarity in age like the topmost peneplain in non-soluble layers (augengeneisses) in Ios (700 m mean altitude). This peneplain was dated by apatite fissiontracking with 13,18 \pm 1,08 M.a. (Hejl, Riedl, Weingartner, 2000).

As distinguished from the Eastern Aegean islands, the geotectonic pattern of the Cyclades wasn't consolidated before the Serravallian/Tortonian intrusion of the plutonites and the Tortonian overthrust of the Aegean nappe. Therefore one can only expect Late Miocene-Lower Pliocene palaeokarst (Riedl, 1982, 1984b). All apatite fission-tracking ages of the peneplains in non soluble layers of the Cyclades show these circumstances. In Tinos, Mikonos, Seriphos, Naxos and Paros the absolute ages reach into the Late Miocene and Lower Pliocene (Hejl, Riedl, Weingartner, 1999, 2000).

Notable on Siros (Riedl, 1981) that somewhat younger Miocene karst generation includes residuals of the marginal karst plains, slope-concavities and pediments adjusted at the karst marginal plains. That Late-MioceneLower Pliocene karst appears also on Siphnos (Riedl, 1983) and Paros (Riedl, 1982b).

In Continental Greece the polje of Ioannina (Epirus) must be interpreted as a polygenetic polje, which got shaped in Late Miocene (Katsikis, 1992), because it reveals incrustations of Upper Pliocene and in Burdigalian times the Jonian zone was still affected by marine sedimentation.

On the Peloponnese a marginal karst plain situated in the marbles, dominates the Mani peninsula occupying $60 \%$ of the Mani's surface. Typical features are represented by humshaped karst domes, mogotes and pediments (Stocker, 1976, Riedl, 1976) adjusted to the two to four km wide marginal karst plain. The pediments are not succeeded by glacis showing thus a significant key feature. The Upper Pliocene transgression discordantly cuts the complex palaeorelief which implies, that the karst pediments and the marginal karst plain as well as the Upper smooth slopes must be older than the Upper Pliocene transgression. The conglomerate mantles with layers of petrified soil sediments (Stocker, 1976) may serve as evidence that these specific palaeokarst landforms developed under a seasonally humid, tropical climate, whereby creeping and sheetflood erosion on thick soil covers may be considered as the essential processes affecting the pediments and controlling the corrosion dynamics of the whole palaeokarst.

Pediments without glacis also dominate the piedmont benchland of Arcadia (Riedl, 1978). Both, the marginal karst plains, located at an average altitude of $1.150 \mathrm{~m}$ and the pediments of the Maenalon Mts. turn out to be older than the ancient surfaces of the glacis of the large intramontaneous basins of the Peloponnees and to be younger than the pre-Neogene palaeokarst of Peloponnese.

The Late Miocene-Lower Pliocene karst corresponds with regard to the pronounced tropical climate by increasing hygric seasonality with the palae-oecological findings of Bernor (1979), Marasti (1979), Kamberis et al. (1992) and Suc et al. (1982).

The Plio/Pleistocene-Older Pleistocene palaeokarst generation we find not only on Pholegandros but also on Paros in the manner of the W-E striking polje of Marathi (Riedl, 1982 a,b) and in the Northern Sporades.

In Skopelos the coastal marginal pediments at an average altitude of $120 \mathrm{~m}$ extend like in the Cyclades across the present-day bays. The pediments are associated with a typical sequence of landforms following a regular pattern. In the depression of Staphylos (Riedl, 1998, Riedl, Papadopoulou, 1998) the pediments merge into glacis connected with karst blind valleys at the counter discharge margin of the block of Mt. Plakes. The blind valleys were transformed into poljes and uvalas. Both types of karst depressions could only develop before the emergence of the island in post-Lower Pleistocene times. Similar circumstances were excellently analyzed on the example of Thasos (Northern Aegean islands) by Weingartner (1994) and on the example of Lichas peninsula by K. Papadopoulou (1998).

The Plio/Pleistocene relief generation in Greece, characterized by the association of pediments and glacis, represents a prominent group of forms that models the Late Miocene-Lower Pliocene primary outline of the large poljes. In the polje of Joannina (Katsikis, 1981), for instance, the topping zone of pediments, which developed after the initial polje had been buried in the Pliocene, may be identified most distinctly in the hum hillside. The associated glacis cut the Pliocene lake sediments. The pediments actualy denote the starting area for the more recent, Pleistocene interplay of forces, above all for the development of asymmetric valleys and limnic abrasion terraces of Late Pleistocene age. These forms indicate a young assemblage whose genetic processes initiated the exhumation of the pre-Upper Pliocene ancient form. A similar karst generation in continental 
Greece have been described by Fink and Verginis $(1974,1976)$ on the example of Acarnania. On the meso-scale of forms, the Plio/Pleistocene-Early Pleistocene palaeokarst generation reveals a close dependency on the ancient surfaces of the intramontanous Neogene basins. In this respect, the basin of Sparta (Riedl 1976) may be considered a most illustrative example. The whole margin of the Parnon Mountains in the east of the basin is occupied by a zone of pediments, 300 to $600 \mathrm{~m}$ wide and developed on Tripolitza limestones. In $520-400 \mathrm{~m}$ altitude, the pediments change to glacis that cut the Upper Pliocene sediments of the basin at an acute angle. On the glacis, we find red soils that are covered by Early Pleistocene breccia composed of sharp-edged slope debris. The whole area of the Parnon Mountains is structured by shallow, troughshaped valleys that end on the Plio/ Pleistocene- Early Pleistocene glacis. The trough-shaped kehltoler were modified by uvalas, karst depressions, and small valley-shaped poljes. Subsequent to the uplift of the Parnon Mountains, the formation of this complex association of paleokarst forms set in during or immediately after the genesis of the glacis.

\section{REFERENCES}

BERNOR R. et al. 1979: The Evolution of „Pontian” Mammal Faunas: Some Zoogeographie, Paleoecological and Chronostratigraphic Considerations. Annales Gıologiques des Pays Helliniques, Athenes, 47: 81-89.

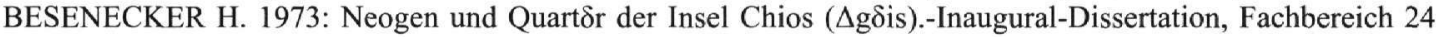
(Geowissenschaften). Freie Universit $\delta$ t Berlin: 196p.

BLANC-VERNET L. et al., 1979: Minuraux argileux et ForaminifӨres dans le Pleistoc $\theta$ ne infurieur de lile de Zante. Annales Giologiques des Pays Helliniques, 7. Int. Congr. on the Medit. Neogene. Hors. Ser. Fasc., I., Athen: 129-138.

BФGER H. 1983: Stratigraphische und tektonische Verknópfungen kontinentaler Sedimente des Neogens im $\Delta$ gois-Raum. Geologische Rundschau, 72, 3, Stuttgart: 771-814.

COMBOURIEU-NEBOUT 1987 : Les premiers cycles glaciaire-interglaciaire de la region Mediterraneenne d, apres 1, analyse palynologique de la serie pleistocene. C.R. Acad. Sci. Paris, 304, ser. II: 533-538.

CVIJIC J. 1893: Das Karstphסnomen. Pencks Geographische Abhandlungen 5, 3, Wien: 215-319.

FINK M., VERGINIS S. 1974: Beitroge zur Karstmorphologie von Nord-Akarnanien (Westgriechenland). Die Hohle, 25, Wien: 1-16.

FINK M., VERGINIS S. 1976: Karstmorphologische Studien in Mittel-Akarnanien (Westgriechenland). Die H $\varphi$ hle, 27: 17-29.

FRYDAS D. 1998: Upper Pliocene diatoms and silicoflagellates from Section Fortessa. Central Crete. Greece. Bulletin of the Geol. Soc. Of Greece, 32/2. Proceedings of the $8^{\text {th }}$ Int. Congr., Patras: 93-100.

GEOLOGICAL MAP OF GREECE 1971: Sheet Chios, Institute for Geology and Subsurface Research, Athen.

GRUND A. 1903: Die Karsthydrographie, Studien aus Westbosnien. Pencks Geographische Abhandlungen 7, 3, Wien: 207p.

HEJL E., RIEDL H., WEINGARTNER H. 1999: Post-plutonic unroofing and morphogenesis of the Attic-Cycladic complex (Aegea, Greece). Manuscript, Salzburg, 29p.

HEJL E., RIEDL H., WEINGARTNER H. et al. 2000: Neotectonics and relief development on the Aegean Islands of Naxos, Paros and Ios (Cyclades, Greece). Manuscript, Salzburg, 30p.

HERGET G 1969: Die Geologie von Nord-Chios ( $\Delta$ gdis). Diss. Marburg, 206.

JACOBSHAGEN V. et al. 1978 : Structure and Geodynamic Evolution of the Aegean Region. Alps, Apennines, Hellenids. Inter-Union Commission on Geodynamics Scientific Report No. 38, Stuttgart: 537-564.

KAMBERNS E. et al. 1992 : Geodynamic and palaeogeographic evolution of the western Peloponnesis (Greece) during the Neogene. Paleontologia I Evolucio 24/25, Sabadell: 363-376.

KATSIKIS A. 1981: Physische Geographie des Beckens von loannina. Diss. Univ. Salzburg.

KATSIKIS A. 1992: Physische Geographie des Beckens von Joannina (Griechen-land) Panepistimio Joanninon Epistimoniki epitirida tou paidagogikou tmimatos. Parartima Ar. 2. Joannina, 163p.

LEHMANN H., 1954: Der tropische Kegelkarst auf den groíen Antillen. Erdkunde, VIII: 130-139.

LOUIS H. 1956: Die Entstehung der Poljen und ihre Stellung in der Karstabtragung auf Grund von Beobachtungen im Taurus. Erdkunde, $\mathbf{X}: 33-53$.

LOUIS H. 1967: Reliefumkehr durch Rumpfflochenbildung in Tanganyika. Geo-grafiska Annales, Ser. A, 49: 256-267.

MARASTI R. et al. 1979: Observations on the paleoclimatic and biogeographic meaning of the Mediterranean Pliocene mollusces. State of the problem. Annales Giologiques des Pays Helliniques. VII Int. Congr. on the Medit. Neog. Hors. Ser. Fasc. II. Athen: 727-734. 
MEISSNER B. 1976: Das Neogen von Ostsamos. Sedimentgeschichte und Korrelation. N. Jahrbuch der Geol. Paldont. Mh., 152, 2, Stuttgart: 161-176.

PAPADOPOULOU K. - VRYNIOTI 1998: KARST LANDFORMS OF LICHAS PENINSULA (NW of EUBOEA ISLAND, GREECE). Theoretical and Applied carstology, Vol. 11-12, Bucuresti.

RIEDL H. 1976: Beitroge zur regionalen Geographie des Beckens von Sparta und seiner Nachbarroume unter besonderer Berócksichtigung der geomorphologischen Verhסltnisse. Arbeiten aus dem Geographischen Institut der Universitסt Salzburg, Salzburg 6: 283-409.

RIEDL H. 1978: Die Formenelemente im Bereich des Arkadischen Zentralzuges und des Westarkadischen Gebirges auf der Peloponnes. Annales Giologiques des Pays Helliniques, Athenes, 46: 209-225.

RIEDL H. 1981: Landschaft und Formenschatz der Insel Syros. Salzburger Exkursionsberichte, 7, Salzburg: 1163.

RIEDL H. 1982a: Vergleichende Untersuchungen zur Geomorphologie der Kykladen unter besonderer Berócksichtigung der Insel Naxos. Salzburger Exkursionsberichte, 8, Salzburg: 9-54.

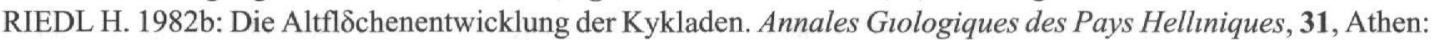
191-250.

RIEDL H. 1983: Geomorphologie der Insel Siphnos. Salzburger Exkursionsberichte, 9, Salzburg: 33-84.

RIEDL H. 1984a: Paleoclimatic aspects of the geomorphology of the Cyclad. Archipelago with reference to methodological problems. Paleobiologie continentale, 14/2, Montpellier: 403-413.

RIEDL H. 1984b: Die Reliefgenerationen Griechenlands. Фsterreichische Osthefte, 26, Wien: 156-176.

RIEDL H. 1989: Beitroge zur Landschaftsstruktur und Morphogenese von Samos und Ikaria. Salzburger Geographische Arbeiten, 18, Salzburg: 143-243.

RIEDL H. 1998: Geomorphologie der Insel Skopelos. Salzburger Geographische Arbeiten, 33, Salzburg: 7-64.

RIEDL H., PAPADOPOULOU-VRYNIOTI K. 1998b: The relief generations on the Island of Skopelos (Sporades). Bulletin of the Geol. Society of Greece, 32/1. Proceedings of the $8^{\text {th }}$ Int. Congr. Patras: 287-295.

STOCKER E. 1976: Klimamorphologische Untersuchungen auf der Mani Halbinsel mit besonderer Berócksichtigung der Formengruppe Glatthang-Pediment-Karstrandebene. Arbeiten aus dem Geographischen Institut der Universitot Salzburg, 6, Salzburg: 91-228.

SUC J.P. \& CRAVATTE J. 1982 : Etude palynologique du pliocene de Catalogne (nord-est de 1,Espagne). Apports a la connaisance de 1, histoire climatique de la Mediterranee occidentale et implications chronostratographiques. Paleobiologie continentale 12(1), Montpellier, 1-31.

THUNELL R. C. 1979: Quantitative Biostratigraphy and Paleoclimatology of the Late Neogene Deep Sea Drilled Sequences from the Mediterranean. Annales Giologiques des Pays Helliniques, Athenes, 47: 1215-1223.

THUNELL R. C. \& WILLIAMS D. F. 1983: The steppic development of Pliocene-Pleistocene palaeoclimatic and palaeoceano-graphic conditions in the Mediterranean oxygen isotope studies of DSDP Sites 125 \& 132, Utrecht Micropalent. Bull. 30, 111-127.

VAVLIAKIS E., SOTIRIADES L., PSILOVIKOS A.1980: The polje of Lekani. East Macedonien. A carstified quaternary tectonic depression. Annales Glologiques des Pays Helliniques, Athenes 30/2: 602-615.

VELITZELOS E. and ZOUROS N. 1998: New results on the petrified forest of Lesvos. Bulletin of the Geol. Society of Greece, 32/2. Proceedings of the $8^{\text {th }}$ Int. Congr. Patras: 133-142.

WALTER H. 1984: Vegetation und Klimazonen. Stuttgart, 382p.

WEINGARTNER H. 1994: Die Insel Thasos. Eine physisch-geographische Synthese. Salzburger Geographische Arbeiten. 24, Salzburg: 166p.

WISSMANN H.v. 1954: Der Karst der humiden heiíen und sommerheiíen Gebiete Ostasiens. Erdkunde, VIII: 122-130.

ZÖTL J. 1961: Die Hydrographie des nordostalpinen Karstes. Steirische Beiträge zur Hydrogeologie, 13, Graz: $183 p$.

ZÖTL J. 1974: Karsthydrologie, Wien und New York, 291p. 